\title{
Responsartikels
}

\section{Die tydgerigtheid van die Bybel en die etiek van Bybellees: respons op die artikel van Gerrie Snyman}

Fika J. van Rensburg

Skool vir Bybelwetenskappe \& Antieke Tale

Potchefstroomkampus

Noordwes-Universiteit

POTCHEFSTROOM

E-pos: Fika.JanseVanRensburg@nwu.ac.za

\begin{abstract}
The time-orientedness of the Bible, and reading the Bible ethically: response to the article by Gerrie Snyman

The Editorial Board of "In die Skriflig" has requested Prof. Fika J. van Rensburg to respond to the article by Prof. Gerrie Snyman ("Homosexuality and time-orientedness: an ethic of reading the Bible?"; p. 715-744 in this edition). Prof. Snyman is critical of the discourse on homosexuality in the Reformed Churches in South Africa, as i.a. verbalised by Prof. Van Rensburg's view that the pronouncement of the Biblical text on homosexuality is a matter of principle and not a cultural prescription bounded by time. Snyman (2006:718) is of the opinion that the criteria Van Rensburg uses to establish whether Scripture portions are time orientated and/or time bound, have no logic to it, but that it reveals clear ideological preferences. In his response Prof. Van Rensburg does not respond to Snyman's argument point by point, but gives a systematic presentation of how he would like to see Reformed theologians establish whether a Scripture portion is timeoriented or time-bound. This he does methodologically and theoretically, as well as practically, at each point indicating how he agrees with or differs from Snyman.
\end{abstract}




\section{Opsomming}

\section{Die tydgerigtheid van die Bybel en die etiek van Bybellees: respons op die artikel van Gerrie Snyman}

Die Redaksie van "In die Skriflig" het prof. Fika J. van Rensburg versoek om op prof. Gerrie Snyman se artikel ("Homoseksualiteit en tydgerigtheid: 'n etiek van Bybellees?", p. 715744 van hierdie uitgawe) te respondeer. Prof. Snyman spreek in sy artikel kritiek uit op die diskoers met betrekking tot homoseksualiteit binne die Gereformeerde Kerke in Suid-Afrika, soos onder andere verwoord deur prof. Van Rensburg se siening dat die Bybelteks se uitspraak oor homoseksualiteit 'n beginselsaak is en nie 'n tydgebonde kulturele voorskrif nie. Snyman (2006:718) oordeel dat die kriteria wat Van Rensburg aanwend om tydgebondenheid en/of tydgerigtheid van Skrifuitsprake te bepaal geen logika het nie, maar slegs spreek van "duidelike ideologiese voorkeure". In sy respons tree prof. Van Rensburg nie punt vir punt met Snyman in gesprek nie, maar gee hy aan die hand van die Skrifuitsprake oor homoseksualiteit 'n tetiese uiteensetting van hoe hy oordeel Gereformeerde teoloë die tydgebondenheid en/of tydgerigtheid van Skrifdele metodologies-teoreties en prakties moet benader. Hy dui ook telkens aan hoe hy saamstem of verskil van Snyman.

\section{Inleiding}

Ek verwelkom hierdie geleentheid tot 'n "in-huis" Gereformeerde akademiese diskussie met Gerrie Snyman wat, soos ek, 'n Gereformeerde teoloog is. Snyman (2006) plaas in sy artikel inderdaad een van die knellendste hermeneutiese probleme van ons tyd op die tafel. Die vraag hoe die tyds- en kulturele gerigtheid van die Bybel hanteer moet word, en watter invloed dit op die gesag van bepaalde Skrifgedeeltes het, speel die afgelope dekades al 'n ingrypende rol in die hantering van verskillende vraagstukke waarvoor gelowiges hulle moes verantwoord. Hierdie diskussie kan daartoe bydra dat daar groter presisie hieroor kom, en dat dit in ons Skrifbeskoulike en hermeneutiese vertrekpunte en in ons omgang met die Skrif verreken word.

In hierdie gesprek sal ons mettertyd (noodwendig oor 'n groter bestek as net die huidge twee artikels) moet uitmaak op watter vlak ons verskil lê:

- 'n Eerste moontlike vlak van verskil: In die bestudering van die homoseksualismevraagstuk word daar noodwendig, soos by 
ander eksegetiese en hermeneutiese vraagstukke, van sekere voorveronderstellings en uitgangspunte uitgegaan. Dit kan wees dat die verskil reeds op hierdie vlak lê. Die een navorser sal die ander navorser se eksegese en hermeneuse as geoorloof of ongeoorloof beoordeel.

- 'n Tweede moontlike vlak van verskil: Indien ons albei se eksegese en hermeneuse geoorloofde eksegese en hermeneuse is (dit is getrou aan die Gereformeerde Skrifbeskouing), kan die verskil op wetenskaplike vlak lê. Hiervolgens moet die standpunte wetenskaplik beoordeel word, deur te bepaal of die eksegese en hermeneuse wetenskaplik geldig of wetenskaplik ongeldig is.

- Die verskil kan ook op 'n derde moontlike vlak lê: Die eksegese en hermeneuse kan meer oortuigend of minder oortuigend wees.

Vanweë die menslike beperktheid en sondigheid, kan dit gebeur dat eksegete wie se eksegese in die lig van die Gereformeerde uitgangspunte geoorloof is en wat wetenskaplik geldige en oortuigende eksegese doen, tog 'n Skrifgedeelte verskillend verstaan. Indien dit by ons twee die geval is, moet ons mekaar ruimte gee binne die Gereformeerde tradisie. Indien die verskil egter op die eerste vlak lê, kan die gesprek natuurlik voortgaan, maar nie langer as 'n "in-huis"-gesprek nie.

Snyman stel in sy artikel Homoseksualiteit en tydgerigtheid: 'n etiek van Bybellees? (2006:717) vrae oor die feit dat ek argumenteer dat dit in die Skrifuitsprake oor homoseksualiteit nie net handel oor kultuur- of tydgebonde uitsprake nie, maar oor 'n dieperliggende altydgeldende beginsel (Van Rensburg, 2005:10-11). Snyman (2006:717) het dit veral oor my oordeel (2005:13) dat die hele Bybel dit duidelik maak dat seksualiteit nie 'n saak van persoonlike voorkeur is nie, maar dat seksualiteit deur die Skrif beperk word tot die huwelik as permanente vertrouensverhouding tussen twee persone, en tweedens dat die huwelik beperk word tot persone van teenoorgestelde geslagte.

Ten grondslag van Snyman se kritiek lê sy oordeel dat die kriteria wat ek aanwend om tydgebondenheid of tydgerigtheid van Skrifuitsprake te bepaal geen logika het nie, maar slegs spreek van "duidelike ideologiese voorkeure" (Snyman, 2006:718).

Ek is dit grootliks met Snyman eens dat daar by Gereformeerdes 'n etiek van Bybellees moet wees waar ons nie die morele visie van die teks volg bloot omdat dit in die Bybel staan nie, maar onder 
andere optimaal moet onderskei "tussen dít wat kultureel bepaal en omlyn is en dít wat as geldende beginsels vir die huidige leser gestel kan word" (Snyman, 2006:718). Ons moet inderdaad eksegetiese willekeur aan bande lê. Dit is egter uit Snyman se artikel duidelik dat, wanneer dit by die toepassing van hierdie beginsel kom, ons van mekaar verskil.

In plaas daarvan om punt vir punt met Snyman op grond van sy artikel in gesprek te tree, spits ek die gesprek toe op die saak in terme waarvan Snyman die metodologie-vraagstukke op die tafel geplaas het, naamlik homoseksualiteit. In die onderstaande gee ek aan die hand van die kern-Skrifuitsprake oor homoseksualiteit 'n tetiese uiteensetting van hoe ek oordeel ons as Gereformeerdes die sogenaamde tydgebondenheid en/of tydgerigtheid van Skrifdele metodologies-teoreties en prakties (moet) benader. Met die oog hierop is my aanpak die volgende:

- Eerstens gee ek die tersaaklike kern-Skrifdele asook my hermeneuse in 'n neutedop, van dié Skrifuitsprake oor die verskynsel dat mense seksueel aangetrokke voel tot persone van hulle eie geslag.

- Daarna noem en beredeneer ek kortliks die Skrifbeskoulike vertrekpunte wat hierdie hermeneuse ten grondslag lê - telkens met ekskurse na Gerrie Snyman se standpunte en argumente.

- Dan noem en beredeneer ek die tersaaklike hermeneutiese vertrekpunte, weer met ekskurse na Snyman se standpunte en argumente.

- Laastens toon ek kortliks aan watter implikasie hierdie hermeneuse van die kern-Skrifdele oor homoseksualiteit het vir die pastorale hantering van gelowiges wat homoseksueel is.

\section{Die kern-Skrifdele oor homoseksualiteit, en my hermeneuse ${ }^{1}$ daarvan}

Die Skrifdele wat in verband met die beoordeling van homoseksualiteit direk tersaaklik is, is die volgende:

1 Gereformeerde hermeneuse is die proses waarin die resultaat van die hele eksegeseproses (grammaties-historiese analise en die teologiese sintese) waarin vasgestel is wat God in die betrokke Skrifdeel openbaar, oorgebring word na die huidige leser/hoorder. 
- Levitikus 18:22: “Jy mag nie 'n homoseksuele verhouding hê nie. Dit is 'n afstootlike sonde."

- 1 Korintiërs 6:9: “... geen mense wat ... homoseksualiteit beoefen 2 ... sal deel kry aan die koninkryk van God nie".

- Romeine 1:24-27: “24Daarom gee God hulle aan die drange van hulle hart oor en aan sedelike onreinheid, sodat hulle hulle liggame onder mekaar onteer. ${ }^{25}$ Dit is hulle wat die waarheid van God verruil vir die leuen. Hulle dien en vereer die skepsel in plaas van die Skepper, aan wie die lof toekom vir ewig. ${ }^{26}$ Daarom gee God hulle oor aan skandelike drifte. Hulle vroue verander die natuurlike omgang in 'n teennatuurlike omgang. ${ }^{27}$ Net so laat vaar die mans ook die natuurlike omgang met die vrou en brand van begeerte vir mekaar. Mans pleeg skandelikhede met mans en bring oor hulleself die verdiende straf vir hulle perversiteit."

- 1 Timoteus 1:10: "mense wat homoseksualiteit beoefen ..., doen wat met die gesonde leer in stryd is."

My hermeneuse van hierdie Skrifdele ${ }^{3}$ is die volgende:

God het seksualiteit vir die permanente, een-tot-een vertrouensverhouding tussen man en vrou geskep. Hierdie hermeneuse hou in dat 'n seksuele verhouding tussen persone van dieselfde geslag nie deel van God se wil is nie. Daar is dus myns insiens geen onduidelikheid oor wat 'n gelowige se houding teenoor homoseksualisme moet wees nie: seksuele verhoudings tussen persone van dieselfde geslag is teen die wil van God, en persone wat volhard in die beoefening daarvan, is besig met 'n ernstige sonde.

\section{Skrifbeskoulike vertrekpunte ten grondslag van hierdie hermeneuse}

Die basiese Skrifbeskoulike vertrekpunt is dat die Bybel die ewige en altydgeldende Woord van God is, en dat God die Bybel deur die

2 "Homoseksualiteit beoefen" is in die oorspronklike twee aparte begrippe: dit dui twee kategorieë homoseksuele mense aan, naamlik dié wat die "manlike" rol in

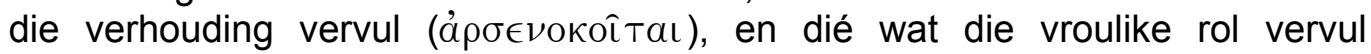
(

3 Die eksegese van hierdie Skrifdele is binne die gereformeerde tradisie deeglik gedoen deur Peet Botha en Jorrie Potgieter. Vergelyk onder andere Botha (2005a), Botha (2005b), Botha \& Van Rensburg (2004) en Potgieter (2005). 
inspirasie van die Heilige Gees tydgerig vir en deur mense laat boekstaaf het.

\subsection{Die Bybel is die geskrewe Woord van God}

Die "van" in die frase "die Bybel is die geskrewe Woord van God" is subjektiewe genitief: God is die Subjek van dit wat in die Bybel geskryf staan. Aangesien Hy ook Hómself in die Bybel openbaar, is Hy inderdaad óók die Objek van die Bybel. God het Homself en sy wil aan mense in skriftelike vorm geopenbaar, en in hierdie proses het Hy van mense en menslike aktiwiteit gebruik gemaak. God se openbaring in die Bybel vind dus plaas in die taal en konteks van die betrokke mense. In hierdie sin is die Bybel God se Woord in mensewoorde (vgl. byvoorbeeld Luk. 1:1-4;4 Openb. 1:1-35). Dit beteken dat die Bybel op só 'n wyse Woord van God is, dat al die historiese en menslike aspekte daarvan ten volle verreken is.

'n Tersaaklike implikasie van hierdie vertrekpunt is dat die verskillende Bybelboeke nie in isolasie van mekaar verklaar kan word nie, maar in onderlinge openbaringshistoriese samehang. 'n Verdere implikasie is dat die Woord van God nie volledig deur die Bybel omvat word nie. Benewens die feit dat die Bybel nie alles sê wat oor God gesê kan word nie, openbaar God Hom ook nog in die skepping.

\subsection{Die Bybel is ewig en altydgeldend}

Die belydenis dat die Bybel ewig en altydgeldend is, beteken in die eerste plek dat erken word dat God die Bybel bedoel het om sy openbaring aan mense van alle tye, plekke en omstandighede te bring; ook dat erken word dat die Bybel gesag het en die openbaring

4 Lukas 1:1-4: "Hooggeagte Teofilus! Daar is baie wat onderneem het om 'n verhaal te skrywe van die dinge wat onder ons gebeur het. ${ }^{2}$ Hulle het dit opgeteken soos dit aan ons oorgelewer is deur die mense wat van die begin af ooggetuies en dienaars van die Woord was. ${ }^{3}$ Daarom het ek dit ook goedgedink om self alles stap vir stap van voor af te ondersoek en die verhaal noukeurig in die regte volgorde vir u neer te skryf. ${ }^{4}$ So kan $u$ te wete kom dat die dinge waaroor u onderrig is, heeltemal betroubaar is."

5 Openbaring 1:1-3: "Wat hier volg, is deur Jesus Christus geopenbaar. God het die openbaring oor wat binnekort moet gebeur, vir Hom gegee om aan sy dienaars bekend te maak. Jesus het toe sy engel gestuur om sy dienaar Johannes dit alles te laat sien. ${ }^{2}$ Johannes is die getuie van wat God gesê en wat Jesus Christus bevestig het; hy getuig van alles wat hy gesien het. ${ }^{3}$ Geseënd is die een wat die woorde van hierdie profesie lees, en die mense wat dit hoor en wat ter harte neem wat daarin geskrywe staan, want die eindtyd is naby." 
van God se wil is. Hierdie belydenis hou verder in dat jy die Bybel ag as die maatstaf vir jou standpunt oor God, jou verhouding met Hom, jou eie leefstyl en jou verhouding met ander mense en met die skepping, en dus ook vir jou houding teenoor homoseksualisme en gelowiges wat hulle homoseksualiteit (wil) uitleef.

Die belydenis dat die Bybel ewig en altydgeldend is, hou egter nie in dat die Bybel op elke probleem waarvoor die mens te staan kom, 'n simplistiese een-tot-een antwoord gee nie. Ten diepste bied God in die Bybel sy openbaring oor Homself (wie Hy is: God, Here, Skepper van alle dinge), oor die wyse waarop Hy verlossing bewerk (dat $\mathrm{Hy}$ in Christus die sonde oorwin en sodoende die verhouding tussen Hom en sy beelddraer herstel tot dié van Vader-kind), en oor hoe Hy as Here en God gedien en geëer word (hoe die verlostes in alles wat hulle doen, sê en dink, moet wys dat hulle vanuit 'n herstelde verhouding met God leef).

In die belydenis van die ewigheid en altydgeldendheid van die Bybel, is dit nodig om 'n duidelike onderskeid te maak tussen dit wat in die Bybel geskryf staan, en die leser se eie verklaring daarvan. Dit wat in die Bybel geopenbaar word, staan vas, maar die leser se verklaring daarvan - te meer nog die leser se hermeneuse daarvan - moet altyd weer aan die Bybel gemeet word. Daarom rus die verantwoordelikheid op die leser om alles in sy/haar vermoë te doen om die eie verklaring te kontroleer. Hierdie kontrole hou onder andere die volgende in:

- Ek gaan nie optree asof ek dink ek is die eerste een wat onder leiding van die Heilige Gees die Bybel bestudeer nie. Ek gaan begaafde persone wat voor my dit ook gedoen het, raadpleeg. Nie om hulle boeke/standpunte gelyk met die Bybel te stel nie, maar om my eie verklaring in die lig daarvan te weeg; om met werklike openheid te gaan kyk of ek nie deur insette van medegelowiges en selfs ander kundiges tot ander insigte gebring word nie.

- Ek gaan volhou met die bestudering van die Bybel en bepaal of ander dele van die Bybel nie lig werp op 'n onderdeel waarmee ek worstel nie.

Om dus ook in praktyk te bely dat die Bybel ewig en altydgeldend is, moet ons as Gereformeerde teoloë die volgende doen:

- Ons moet elkeen ons eie voorveronderstellings so duidelik en logies moontlik stel. 
- Ons moet erken dat ons in 'n bepaalde teologiese tradisie staan en dat ons Bybeluitleg deur daardie tradisie beïnvloed word.

- Ons moet erns maak met die feit dat elke onderdeel van die Bybel in 'n bepaalde tyd geskryf is en só ingeklee is dat dit op daardie tydsomstandighede gerig is.

- Ons moet deurentyd daarmee rekening hou dat ons eie tyd met sy probleme maak dat ons die Bybel op 'n eie manier lees. Daarom moet ons alles in die stryd werp om te bepaal hoe ons eie tydsomstandighede ons uitleg van die Bybel beïnvloed en om op ' $n$ verantwoordbare wyse te kontroleer of ons uitleg geldig is. Die Bybel is immers bedoel ook vir ons tyd en omstandighede en daarom moet ons profeties in staat wees om by wyse van hermeneuse die Skrif se lig ook op ons eie tydsomstandighede te laat skyn.

Die Gereformeerde teoloog maak dus nie die Bybel verantwoordelik vir sy/haar verklaring en hermeneuse nie. Oor moeilike sake bly dit 'n biddende soeke na die korrekte verklaring, om ook ten opsigte van die onsekerhede wat nog bestaan, steeds meer duidelikheid te kry. Dit is egter nie 'n hooplose soektog nie. Alhoewel ons weet dat ons in hierdie bedeling nie die volmaakte begrip van God se openbaring in die Bybel (ook oor leefstylsake) volkome sal verstaan nie, 6 neem dit nie weg dat ons alles inspan om juis daardie volmaaktheid te bereik nie (vgl. Filip. 3:12-14;7 vgl. Greijdanus, 1946:34). Ons doen dit met oorgawe, asof dit moontlik sou wees om tog die volmaakte korrekte insig in onder andere die leefstylvoorskrifte in die Bybel te kry.

6 Oor ons verlossing en die wyse waarop God ons verlossing bewerk, is daar nie twyfel oor hoe ons die Bybel moet verstaan nie. Hierdie twyfel bestaan egter dikwels ten opsigte van Skrifdele waarin God gedragsvoorskrifte gee, juis wanneer hierdie voorskrifte ingebed is in bepaalde fasette van die kultuur van die samelewing waarbinne die betrokke openbaring gegee is.

$7 \quad$ Filipense 3:12-14: "12Ek sê nie dat ek dit alles al het of die doel al bereik het nie, maar ek span my in om dit alles myne te maak omdat Christus Jesus my reeds Syne gemaak het. ${ }^{13}$ Broers, ek verbeel my nie dat ek dit alles al het nie. Maar een ding doen ek: ek maak my los van wat agter is en strek my uit na wat voor is. ${ }^{14} \mathrm{Ek}$ span my in om by die wenstreep te kom, sodat ek die hemelse prys kan behaal waartoe God my geroep het in Christus Jesus." 
In dit alles gryp die gelowige vas aan die belofte van Christus dat die Heilige Gees ons in die volle waarheid lei (Joh. 14:26;8 16:139). Die leiding van die Gees vind op geen ander manier plaas nie as deur die Woord self (vgl. Joh. 15:1-7). Juis daarom maak die gelowige eksegeet erns daarmee om alles in te span om 'n aanvaarbare, geldige verklaring en toepassing van elke Skrifdeel te gee. Die maatstaf vir aanvaarbaarheid en geldigheid is egter nie die leser se eie oordeel nie maar hy/sy doen dit op grond van die Skrif self. Dit geld ook vir die Skrifdele wat vir die beoordeling van homoseksualisme tersaaklik is.

Ek is dit dus met Snyman (2006:723) eens dat die "subjektiewe element ... bewustelik verreken behoort te word". Dit kan myns insiens nie anders nie. Die oplossing lê nie daarin om hierdie perspektief te negeer nie, maar om dit, soos hierbo gestel is, onder woorde te bring. Terselfdertyd beteken die erkenning van hierdie "subjektiewe element" nie dat die openbaring van 'n teks nou totaal ontoeganklik is, en "willekeurig" verstaan word nie.

\subsection{Die Bybel is deur die Heilige Gees geïnspireer}

Die Bybel is God se Woord, en die Bybel self maak duidelik dat God dit wat $\mathrm{Hy}$ aan mense openbaar, deur mense laat opteken in menslike woorde en geskrifte (vgl. byvoorbeeld 2 Tim. 3:16-17;10 2 Pet. 1:19-2111). In hierdie proses het God die produk van die

8 Johannes 14:26: "26 en wanneer die Vader in my Naam die Voorspraak, die Heilige Gees, stuur, sal Hy julle alles leer en julle herinner aan alles wat Ek vir julle gesê het".

9 Johannes 16:13: "133anneer Hy kom, die Gees van die waarheid, sal Hy julle in die hele waarheid lei. Wat Hy sal sê, sal nie van Homself kom nie: Hy sal net sê wat Hy hoor, en Hy sal die dinge wat gaan kom, aan julle verkondig."

102 Timoteus 3:16-17: " ${ }^{16}$ Die hele Skrif is deur God geïnspireer en het groot waarde om in die waarheid te onderrig, dwaling te bestry, verkeerdhede reg te stel en 'n regte lewenswyse te kweek, ${ }^{17}$ sodat die man wat in diens van God staan, volkome voorberei en toegerus sal wees vir elke goeie werk."

112 Petrus 1:19-21: "19 En dit het vir ons die boodskap van die profete nog meer bevestig. Hierdie boodskap is soos 'n lamp wat in 'n donker plek skyn. Julle sal goed doen as julle in sy lig bly totdat die dag aanbreek en die môrester opkom in julle harte. ${ }^{20}$ Dít veral moet julle weet: geen profesie in die Skrif kan op grond van eie insig reg uitgelê word nie, ${ }^{21}$ want geen profesie is ooit deur die wil van 'n 
menslike skrywers geïnspireer. Die wyse waarop die inspirasie plaasgevind het, word getipeer as organiese inspirasie: God het die skrywers se arbeid só geïnspireer dat dit wat hulle geskryf het, sy openbaring effektief en voldoende oordra. Hierdie inspirasie het egter nie gebeur met uitsluiting van die skrywers se eie persoonlikhede, agtergrond en ander omstandighede nie; hulle het elkeen geskryf binne die konteks van hulle eie kultuurhistoriese situasie.

Hierdie organiese inspirasieteorie hou in dat dit ongeldig is om te stel dat sekere dele van die Bybel menslik is, asof die Bybelleser dan die goddelike dele uit die Bybel moet selekteer. Die hele Bybel is terselfdertyd Goddelik én menslik. Meer noukeurig geformuleer: die Bybel is honderd persent God se Woord en honderd persent deur mense geboekstaaf (vgl. Greijdanus, 1946:29).

\subsection{Die Bybel is tydgerig maar nie tydgebonde nie}

Die tydgerigtheid van die Bybel hang nóú saam met die organiese inspirasie van die Bybel (Coetzee, 1995:16). Die menslike skrywers het die taal, idoom, literêre genres en argumentasiestyl van hulle tyd gebruik om die geïnspireerde Woord op skrif te stel. Daarby het God deur die menslike skrywers, juis vanweë die organiese aard van die inspirasie, sy Woord op die situasie en lewensomstandighede van die eerste lesers gerig. Die Bybel is dus geformuleer in die taal en idioom wat die eerste lesers sou verstaan, en praat met hulle binne hulle eie historiese situasie en lewensomstandighede.

Die tydgerigte karakter van die Bybel kom dus op die volgende neer: in sy gesagvolle Woord het God, deur middel van menslike skrywers, aan die eerste lesers bekendgemaak hoe hulle as dankbare verlostes hulle lewe te midde van die destydse omstandighede moet inrig, en watter geloofsperspektief hulle op die problematieke van hulle tyd moes hê. Ook het Hy aan hulle bekendgemaak watter optrede en gesindheid vir Hom verwerplik is, en watter volgens sy wil is.

Dieselfde geld ook vir samelewingskonvensies. In sy Woord laat God blyk watter samelewingskonvensies Hy goedkeur en watter Hy verwerp. God doen dit direk (bv. die afkeur van mense-offers en ook dat daar seksuele verhoudings tussen persone van dieselfde geslag

mens voortgebring nie. Nee, deur die Heilige Gees meegevoer, het mense die woord wat van God kom, verkondig." 
is) of indirek (bv. die goedkeuring van die destydse Romeinse erfreg en die afkeur van uitbuiting van mense deur slawerny), dadelik (bv. mense-offers) of met verloop van tyd (bv. poligame huwelike en slawerny), en soms deur 'n duidelike korrektief op sulke samelewingskonvensies te stel (bv. die huwelik). Hierdie openbaring van God ten opsigte van watter optrede en perspektiewe volgens sy wil is, bly altyd geld - ongeag samelewingskonvensies.

Die tydgerigte karakter van die Bybel beteken dus nie dat die Bybel tydgebonde is nie. Dit is nie tot die historiese situasie en lewensomstandighede van die eerste lesers/hoorders beperk of daarbinne vasgevang nie. God se Woord reik déúr die tyd en omstandighede van die eerste lesers verder en spreek tot mense van alle tye - ook vandag, en ook oor homoseksualiteit.

Net soos die tale waarin die Bybel geskryf is, vertaal moet word om latere lesers elkeen in hulle eie taal te bereik, so moet ook die tydgerigtheid van die Bybel deur hermeneuse "vertaal" word om latere lesers elkeen binne hulle eie tyd en omstandighede te bereik. Net soos 'n gewone vertaling met groot omsigtigheid moet plaasvind sodat die Bybel in die ontvangertaal (so ver as moontlik) niks anders sê as wat in die oorspronklike tale gesê is nie, só moet ook die aktiwiteit van hermeneuse daarop gerig wees dat God se openbaring duidelik en onvervals tot die hedendaagse mense in hulle eie situasie en omstandighede kom. Waar gewone vertaling egter noodwendig slegs deur spesialiste gedoen (kan) word, is elke gelowige Bybelleser noodwendig "kultuurvertaler" in die gewone leesproses. Hoe meer ingelig die leser is, hoe geldiger kan hierdie hermeneuseproses plaasvind.

Snyman (2006:716) verteken die werklike stand van sake as hy stel: "Die onderskeid tussen tydgerigtheid en tydgebondenheid binne die hermeneutiek van die GKSA is 'n instrument om te kyk wat in die Bybelteks 'n imperatief daarstel vir die hedendaagse lewe en wat uiteindelik as verpakking van Godsopenbaring kan geld." Die onderskeid tussen tydgerig en tydgebonde is maar een van die meganismes op grond waarvan bepaal word hoe 'n Skrifuitspraak as oproep vir vandag geld, en watter rol die kulturele konteks daarin speel. Ander sulke meganismes is onder andere die tekstuele konteks en die openbaringshistoriese lyne. 


\section{Hermeneutiese vertrekpunte ten grondslag van hierdie hermeneuse}

\subsection{Die grammaties-historiese benadering}

Die hermeneutiese model wat gebruik is om by die bostaande hermeneuse van die kern-Skrifdele oor homoseksualiteit uit te kom, is die grammaties-historiese metode. In hierdie metode dien wat in die Bybel geskrywe staan (die grammatiese aspek daarvan, waarby taal, styl, idioom en literêre genre ingesluit is) as grondslag vir die eksegese. Die eksegeet gebruik hierdie metode om rekenskap te gee van dit wat in die Bybel geskrywe staan. Uitgaande van die organiese inspirasie van die Bybel en die gevolglike tydgerigtheid daarvan, word daarna gestreef om dit wat in die Bybel geskryf staan, te verstaan binne die historiese konteks waarop dit gerig is (waarby sowel die openbaringshistoriese konteks as die historiese en kulturele omstandighede van die outeur en die eerste lesers/hoorders ingesluit is).

\subsubsection{Die "historiese"-komponent binne die grammaties-historiese benadering 12}

\subsubsection{Die openbaringshistoriese konteks}

Die Skrifdele oor homoseksualiteit is gelees met die gereformeerde belydenis as vertrekpunt (veral Artikels 2-7 van die Nederlandse Geloofsbelydenis). Daarvolgens openbaar God in sy Woord Homself, 13 ons verlossing 14 en sy wil. 15 Hierdie drievoudige skopus van die Skrif (God en sy eer; ons verlossing; sy wil) staan in direkte samehang met mekaar: as Here en Koning eis God geregtigheid en as almagtige God kan alleen Hy volkome verlossing bewerk; as verlostes moet ons uit dankbaarheid sy wil leer ken en daarvolgens leef, want só, deur sy wil te doen, erken ons Hom as God en Here en bring ons aan Hom die verskuldigde eer.

12 Die "grammaties"-komponent van die grammaties-historiese benadering is in hierdie diskussie buite spel en daarom word net gefokus op die "historiese"komponent.

13 Wie Hy is: God, Skepper, Here en Koning aan wie alle eer toekom (NGB, Art. 1, 2, 8-13).

NGB, Art. 2, 7, 14-23.

15 Wat die verlostes tot sy eer moet gehoorsaam (NGB, Art. 2, 7, 24). 
Uit bogenoemde volg dat die openbaringshistoriese ondersoek na homoseksualisme as deel van die Skrifopenbaring van God se koninkryk hanteer word. Kenmerkend van God se koninkryk is dat $\mathrm{Hy}$ in geregtigheid regeer. Sy wil vir die kerk en die wêreld doen niemand ooit enige onreg aan nie, maar is van die begin tot die einde geregtigheid. Die mens ervaar God se wil dikwels as onreg (vgl. byvoorbeeld die weerstand teen die Skrifleer oor die uitverkiesing), maar dit is bloot die gevolg van die mens se gebrekkige insig.

God se wil ten opsigte van homoseksualisme, soos Hy dit in die Skrif tot openbaring bring, kan dus geen onreg bevat nie. In sy koninkryk duld Hy geen onreg teen enigeen nie, ook nie teen persone wat seksueel aangetrokke voel tot persone van dieselfde geslag nie.

Dit is nie slegs uit die homoseksualiteit-Skrifdele nie, maar uit die hele Bybel16 duidelik dat seksualiteit nie 'n saak van persoonlike voorkeur is nie. In die eerste plek is dit beperk tot die huwelik as permanente vertrouensverhouding tussen twee persone, en in die tweede plek is die huwelik beperk tot persone van teenoorgestelde geslagte.

\subsubsection{Die kultuurhistoriese konteks}

Die boeke van die Bybel bied (binne die raamwerk van bogenoemde skopus) God se openbaring op situasies en probleme van ander kulturele, sosiale en godsdienstige omstandighede as ons s'n tans in die een-en-twintigste-eeuse Suid-Afrika. Omdat die Bybelboeke gegee is vir die lesers om te verstaan, kon hulle - binne die perke van die subjektiewe verstaansprobleme waarna Greijdanus (1946:36) verwys - verstaan wat die Here daarin aan hulle bekend maak. Dikwels kan die hedendaagse leser die krag van die Bybelse boodskap van 'n boek of perikoop in duideliker reliëf en met groter duidelikheid verstaan, wanneer hy/sy konstrueer hoe die betrokke perikoop/boek binne sy ontstaanstyd verstaan is. Vir sulke Skrifdele is dit nodig om die bes kontroleerbare konstruksie van die kultuurhistoriese konteks van die outeur en die eerste lesers/hoorders te

16 Die verbod op homoseksualisme word deurlopend, onveranderd en onverdun reg deur die Skrif herhaal. Die Skrif onderskei hierdie verbod van ander verbiedinge en gebiedinge wat in die Ou Testament teëgekom word, en wat dan óf nie weer in die Bybel herhaal word nie, óf aangepas herhaal word. 
maak. Hiervoor moet die kultuurhistoriese inligting wat die Bybel self bied, op verantwoordelike wyse aangevul word met inligting uit buite-tekstuele bronne.

Die data wat nodig is vir die konstruksie van die kultuurhistoriese konteks, is - veral vir die Nuwe Testament - geredelik beskikbaar. Die verdiskontering van hierdie konstruksie in die verklaarproses lewer egter etlike teoretiese en praktiese probleme op.

- Een uiterste is om hierdie data bloot as die interessante agtergrondgegewens te beskou, so asof dit wat in die Bybel geskrywe staan nie werklik daardeur geraak word nie.

- Andersyds is daar weer dikwels die neiging om tot 'n ander uiterste te gaan. Elliott (1981:21) stel byvoorbeeld dat elke NuweTestamentiese boek "like all documents of the early Christian movement, is a product of and a contribution toward a social world in the making".

- 'n Derde probleem kom egter by. Die wyse waarop in die verklaarproses met die kultuurhistoriese gegewens van die eerste eeu omgegaan word, het beslissende implikasies vir die wyse waarop die sosiale en politieke gegewens van die huidige tyd in die hermeneuse verreken word.

Elkeen van die tersaaklike Skrifdele word beskou as gerig op die sosiale en politieke werklikhede van die ontstaanstyd van die betrokke boek. Dit gaan oor werklike persone wat deel van 'n dinamiese samelewing was en wat met daardie samelewing in interaksie was. Dit beteken egter nie dat die Bybel 'n blote kultuurproduk is nie. God het besluit om sy waarheid juis in hierdie spesifieke konteks te openbaar.

Die betrokke Skrifdele is verklaar met deeglike inagneming van die kultuurhistoriese gegewens wat die Bybel self voorsien, aangevul deur gegewens uit buite-tekstuele bronne. Die benadering waarvolgens dit gebeur, is 'n gebalanseerde kultuurhistoriese benadering: 'n historiese benadering (teenoor 'n sosio-wetenskaplike benadering), ${ }^{17}$ verryk deur die vrae wat sosiaal-wetenskaplikes vra

17 Dié twee benaderings werk met dieselfde buite-tekstuele gegewens: die sosiale en politieke omstandighede van die tydvak waarin die betrokke boek ontstaan het. Die verskil lê egter in die metodes wat gebruik word om daardie gegewens by die konstruksie van die buite-tekstuele konteks van die betrokke Bybelboek/ perikoop te verreken. Vanuit 'n sekere hoek bekyk, vorm 'n suiwer sosiowetenskaplike benadering en 'n suiwer kultuurhistoriese benadering twee pole 
en die resultate van die modelle wat hulle gebruik. 18 Dit beteken dat die benadering emies ${ }^{19}$ is, en nie eties 20 nie. Op hierdie wyse raak die verklaarder deurdrenk met die data en verskynsels uit die era van die betrokke Bybelboek, sonder om doelbewus met 'n vooropgesette teorie of model die data en verskynsels te bekyk.21

Om te bepaal op watter manier (hoe) opdragte wat situasiegerig is ook as blywende imperatiewe bedoel is (oftewel: om te bepaal hoe opdragte met historiese gesag ook normatiewe gesag het), moet die eksegeet eers die teks binne sy kultuurhistoriese konteks lees, en

van 'n kontinuum. Elke persoon wat navorsing doen oor die kultuurhistoriese konteks van 'n Bybelboek, bevind hom/haar êrens op hierdie kontinuum: óf neigend nader aan die suiwer sosio-wetenskaplike, of nader aan 'n kultuurhistoriese benadering. Hierdie twee pole kan soos volg getipeer word: (1) By die sosiaal-wetenskaplike benadering funksioneer die uitgangspunte van die sosiaal-wetenskaplike dissiplines as vertrekpunte, terwyl die kultuurhistoriese benadering histories is. (2) Die sosiaal-wetenskaplike benadering is sosiologies, terwyl die kultuurhistoriese benadering sosiaal is. Dit hou onder andere in dat in die konstruksie van die kultuurhistoriese konteks van die betrokke Bybelboek/ perikoop, die sosiaal-wetenskaplike benadering op sosiologiese teorieë daargestel op grond van die navorsing van huidige sosiale verskynsels konsentreer, terwyl die kultuurhistoriese benadering op die sosiale verskynsels van die eerste eeu konsentreer.

18 Die gebreke van 'n "suiwer" kultuurhistoriese of 'n "suiwer" sosiaal-wetenskaplike metode is die volgende: (1) Die "suiwer" kultuurhistoriese metode gaan daaraan mank dat die beoefenaar in teorievergetelheid verkeer: daar word op 'n intuïtief-naïewe wyse met die sosiale gegewens gewerk, asof dit moontlik is om teorievry te werk. Intussen word nie teorievry gewerk nie, maar wel met 'n intuïtiewe en naïewe teorie - ongedefinieer en ongetoets, en daarom ook grootliks onkontroleerbaar. (2) Die "suiwer" sosiaal-wetenskaplike metode gaan daaraan mank dat die beoefenaar se fokus eensydig ingestel is op kontemporêre teorieë en modelle, en dat die gegewens uit die tydvak van die betrokke boek sekondêr hanteer word.

19 'n Emiese benadering laat die klem val op die situasie van destyds. Data en verskynsels word beskryf in terme van die funksies binne die destydse samelewing. Die data en verskynsels dikteer as't ware die ondersoek.

20 'n Etiese benadering bestudeer ook die situasie van destyds, maar in terme van teorieë en modelle wat in die huidige tyd ontwikkel is op grond van data en verskynsels in huidige samelewings. Die ondersoek word gedikteer deur die betrokke teorie/model.

21 Dit wil nie sê dat hier beredeneer word dat 'n emiese benadering nie teoriebepaald is nie. Wat die argument wel inhou, is dat die emiese benadering die data met betrekking tot die buite-tekstuele konteks van die boek nie met (en: in terme van) 'n sosiologiese model benader nie. Geen benadering is teorievry nie, en daarom is dit noodsaaklik dat elke eksegeet sy/haar interpretasieteorie eksplisiet maak. Sodoende word die effek daarvan op die verklaring meetbaar en kontroleerbaar. 
op grond van die tekstuele konteks en die openbaringshistoriese Skriflyne tot 'n beslissing probeer kom.

By die vasstelling of 'n bepaalde opdrag slegs deel uitmaak van die kultuurhistoriese inkleding van die teks of nie, is die hermeneutiese reël dat die Skrif sy eie verklaarder is, deurslaggewend. Met ander woorde: die eksegeet kan nie net op grond van buitetekstuele bronne of bloot op grond van subjektiewe oorwegings besluit dat 'n bepaalde Skrifopdrag as kultuurhistoriese inkleding beskou moet word nie; die Skrif self moet hierin geraadpleeg word. Een van die maniere waarop die Skrif geraadpleeg word, is om te kyk na die begronding van die betrokke oproep. Oproepe wat in 'n geopenbaarde verlossingsfeit begrond is, kan beskou word as 'n blywende oproep; oproepe wat in kutuurhistoriese argumente begrond is, kan beskou word as 'n oproep wat net binne die betrokke kultuur geld, byvoorbeeld Paulus se oproep in 1 Korintiërs 11:2-16 dat vroue hulle koppe tydens die erediens moet sluier. Daar is duidelike merkers 22 in die teks dat hierdie gedragskode vir daardie spesifieke situasie geld, en dat dit gemotiveer word deur 'n dieperliggende altydgeldende beginsel.

By die homoseksualiteit-Skrifdele is daar juis geen aanduiding dat die oproepe in hierdie verband kultuurhistories begrond is nie. Inteendeel, Paulus gaan juis dwars teen die samelewingskonvensie in. In weerwil van sy verklaarde bedieningstrategie om "vir almal alles te word om in elk geval sommige te red" (1 Kor. 9:22), veroordeel en verbied hy homoseksuele gedrag in die strengste terme.

22 Paulus maak in verband met die vrouekwessie (anders as by die homoseksualiteitskwessie) dit self duidelik dat hy die beginsel wat hy stel, oorbring na 'n kultureel-bepaalde situasie. Hy doen dit deur in 1 Korintiërs 11:6 te sê dat dit vir 'n vrou lelik (ai $\sigma \times \rho o ́ v)$ is om haar hare af te sny of te skeer. Hiermee sluit hy waarskynlik aan by die destydse beskouing oor haarstyl. Die mode destyds was dat ' $n$ man minder hare het as 'n vrou; dit was die algemene

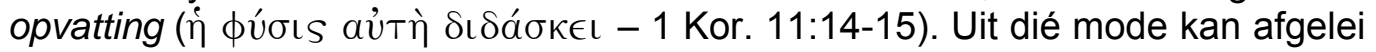
word dat geglo is vroue is bedoel vir lang hare (met nog iets ekstra soos ' $n$ hoofbedekking) en mans vir kort hare (sonder dat 'n hoofbedekking mag bykom). Hellenistiese borsbeelde wys ook hoedat mans in Paulus se tyd met kort hare en vroue met lang hare voorgestel is. Daarom kan Paulus die lesers

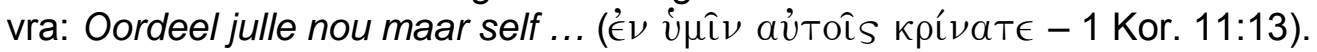




\begin{abstract}
In die geval van homoseksuele verhoudings is die opdrag dus sélf die beginsel; daar is nie ' $n$ ander dieperliggende beginsel wat in die eerste eeu op een manier toegepas is, en hedendaags op ' $n$ ander manier toegepas moet word nie.

Dit is dus nie op grond van subjektiewe oorwegings nie soos Snyman (2006:718) beweer - dat die oproepe oor homoseksualiteit as 'n beginselsaak beskou word, en nie as 'n tydgebonde kulturele voorskrif nie.
\end{abstract}

\title{
4.1.2 Teologiese sintese binne die grammaties-historiese benadering
}

Die teologiese sintese 23 wat volg op die analitiese deel van die eksegese is in 'n sekere sin die belangrikste deel van die Skrifuitleg. Hierdie teologiese sintese verg van die eksegeet onderskeidingsvermoë, die gawe van interpretasie, wat slegs die Heilige Gees verleen. Hierdie gawe is egter nie 'n soort "inwendige lig" wat buite die Skrif om gegee word nie. Die eksegeet ontvang dit juis in die besigwees met die Skrif.

Noukeurige grammaties-historiese eksegese lei tot die bepaling van die diepe sin van 'n Skrifdeel (Grosheide, 1929:65). Hierdie diepe betekenis word nie met verloop van tyd 'n ander betekenis nie. In sy besigwees met die betrokke Skrifdeel sien die verklaarder ook ander Skrifdele raak waarmee die Gees hom/haar só lei dat hy/sy duideliker sien hoe hierdie Skrifdeel verstaan moet word, ook binne die huidige tyd en omstandighede.

Die teologiese sintese is net so onderworpe aan wetenskaplike kontrole as die ander fasette van die eksegese. Die gewone wetenskaplike weg is dat die teologiese sintese rekenskap moet gee van al die onderdele van die Skrifdeel. Die teologiese sintese mag nie die betekenis van die teks verlê tot iets anders as wat daar staan nie. Dit wil deurdring tot die kern van die openbaring van God in die teks, en hierdie openbaringsboodskap moet dan in die hermeneuseproses oorgedra word na die omstandighede van vandag.

23 Grosheide (1929:64) verwys in hierdie verband na die sintetiese eksegese of die bepaling van die dieper sin. Sommige navorsers verwys daarna as die teologiese eksegese, as 'n derde stap na die grammatiese en die historiese eksegese (vgl. Berkhof, 1971:133 e.v.). 
Baie navorsers ervaar 'n beroep op die leiding van die Heilige Gees in akademiese gesprekvoering as ongeldig. In die gesprek met Snyman is dit egter geldig, aangesien ons albei vanuit die Gerefomeerde paradigma redeneer. Die "gawe van interpretasie" maak die ontvanger juis nederig, want die besef is daar dat hierdie vermoë nie self ontwikkel is nie, maar as geskenk ontvang is. Die eksegeet besef ook dat hy/sy nie die eerste persoon is wat hierdie gawe van die Gees ontvang nie. Daarom wil die eksegeet ook met dankbare erkenning steun op die insigte van ander persone wat in hulle navorsing oor 'n bepaalde Skrifgedeelte of oor 'n bepaalde problematiek ook deur die Gees gelei is.

\subsection{Die verrekening van die huidige konteks in die hermeneuse}

Die tersaaklike fasette van die huidige konteks (sosiaal, ekonomies, polities, godsdienstig, ensovoorts) is só in die hermeneuse verreken dat dit tot 'n geldige toespitsing van die eksegese lei.

Hoe beter die sosiale en politieke omstandighede van die betrokke Bybelboek gekonstrueer is, hoe beter kan 'n geldige toespitsing daarvan op die huidige konteks plaasvind. Sodoende kan op 'n wetenskaplik-verantwoordbare wyse bepaal word watter tipe sosiale en politieke situasies vandag deur die betrokke Skrifdele "belig" word. Die betrokke Skrifdeel voorsien as't ware die kragtige soeklig wat spesifieke fasette van die huidige konteks in die kalklig bring. Die betrokke perikoop en sy konteks demarkeer dus self watter tipe sake geldig in die huidige konteks belig kan word.

Dit beteken nie dat die sosiale konteks van die huidige hoorders bepalend mag wees vir wat God sê nie, of 'n veto kan plaas op die resultaat van die eksegese nie. Daarom geld dieselfde wetenskaplike kontrole by dié hermeneuse as wat by die teologiese sintese geld: dit moet berus op die resultate van die eksegese en sorgvuldig rekenskap gee van al die onderdele van die teks. 
Snyman maak op verskillende maniere die huidige omstandighede bepalend vir die hermeneuse, tot so 'n mate dat dit 'n veto plaas op die resultaat van die eksegese.

Snyman (2006:736) doen dit byvoorbeeld met behulp van interseksualiteit: "Die uitdaging is om die aard van seksualiteit, gender en seks in die lig van interseksualiteit in heroorweging te neem. Die huidige teologiese skema forseer die interseksueel om deel te word van 'n paradigma teen fisiese en psigologiese koste." Hiermee maak hy asof die verskynsel en herkenning van interseksualiteit by iemand, die Bybelse voorskrif ophef. Net so min as wat iemand se genetiese geneigdheid tot alkoholverslawing daardie persoon onthef van die oproep om nie alkohol te misbruik nie, net so min kanselleer iemand se interseksuele status die oproep teen homoseksuele verhoudings.

Dit is verder belangrik om raak te sien dat nie een van die kern-Skrifdele handel oor 'n persoon se seksuele oriëntasie, oor 'n individu se aangebore toegeneentheid tot óf die eie óf die ander geslag nie. Of iemand heteroseksueel, homoseksueel of interseksueel is, is dus nie op sigself deurslaggewend vir ' $n$ geldige verstaan van die kern-Skrifdele nie. Dit gaan oor wat die persoon met sy/haar seksualiteit (en seksuele oriëntasie) doen!

Weer is die vergelyking met alkoholisme nuttig: dat iemand aan alkohol verslaaf kan raak, word nie in die Bybel ontken nie. Dit is deel van die gebrokenheid van die bedeling waarin ons leef. 'n Alkoholis kan egter 'n "aktiewe" alkoholis wees, of 'n nie-meer-drinkende, gerehabiliteerde alkoholis. Die Bybel verbied dat die alkoholis vrye teuels gee aan sy/haar natuurlike drang om alkohol in te neem. Die sonde lê dus nie in die eerste plek daarin dát die persoon ' $n$ alkoholis is nie, maar dat die alkoholis aanhou drank gebruik. 
Net so geld hierdie argument vir homoseksuele verhoudings. Dat daar homoseksueles is, dra geen twyfel nie. Dit is deel van die gebroke bedeling waarin ons leef. Persone met 'n homoseksuele oriëntasie word egter volgens die Bybel deur God verbied om vrye teuels te gee aan hulle voorkeur vir 'n verhouding met iemand van hulle eie geslag. 24 Hulle mag dus nie aan die drang om 'n seksuele verhouding met iemand van dieselfde geslag te hê, toegee nie. Hulle homoseksuele oriëntasie is nie in die eerste plek sonde nie, maar wel wanneer hulle toegee aan die drang tot die uitlewing van daardie oriëntasie.

\subsection{Hermeneuse as gawe van profesie}

Ten einde te kan sê wat God aan ons "hier, vandag" sê (vgl. Grosheide, 1929:66), gaan die eksegese oor na die hermeneuse, die proses waarin die resultaat van die hele eksegeseproses (waarin vasgestel is wat God in die betrokke Skrifdeel openbaar), oorgebring word na vandag. Vir die hermeneuseproses is daar nie vasgestelde reëls nie, maar die gawe van profesie wat God deur sy Gees gee, is onontbeerlik (vgl. Rom. 12:6-7;25 1 Kor. 14:326).

\subsection{Geen formeel-meganiese reëls nie}

Aangesien die hele eksegeseproses, in sy grammatiese fasette en in sy historiese fasette, maar veral in die proses van teologiese sintese en hermeneuse, in werklikheid nie sonder die interpretasiegawe van die Heilige Gees kan geskied nie, is dit nie moontlik om dit as 'n meganiese toepassing van hermeneutiese reëls te beoefen nie. Ook in die bepaling van wat God se blywende opdrag vir ons vandag werklik is, en wat slegs as tydgebonde opdragte beskou kan word, moet die Skrifverklaarder terwyl hy/sy werk, bid dat die Heilige

24 Presies só word die heteroseksueel verbied om buite die huwelik vrye teuels aan sy/haar seksualiteit te gee. Daar is dus wel sprake van 'n sekere "gelykberegtiging" in die Bybelse uitsprake.

25 Romeine 12:6-7: "En ons besit genadegawes wat verskil volgens die genade wat aan ons gegee is: ${ }^{7}$ is dit profesie, na die maat van die geloof; of bediening, in die werk van bediening; of wie leer, in die lering."

261 Korintiërs 14:3: "Maar hy wat profeteer, spreek tot die mense woorde van stigting en troos en bemoediging." 
Gees hom/haar die insig sal gee om te interpreteer en om die hermeneuseproses geldig te laat verloop.

\section{Die pastorale hantering van 'n homoseksueel}

Hierdie hermeneuse kan verkeerdelik die indruk skep dat daarmee beweer word dat God wil hê daar moet geen simpatie met homoseksueles wees nie. Inteendeel, Paulus gee duidelike riglyne vir die hantering van 'n medegelowige se sonde: "As iemand in die een of ander sonde val, moet julle wat julle deur die Gees laat lei, so iemand in 'n gees van sagmoedigheid reghelp. En pas op: jy kan self ook in versoeking kom. Dra mekaar se laste, en gee op dié manier uitvoering aan die wet van Christus" (Gal. 6:1-2). Homoseksuele persone mag dus nie met 'n hoogmoedige gesindheid benader word nie. 27

Die hermeneuse dat God homoseksuele verhoudings verbied, neem dus nie die verantwoordelikheid weg om die liefde van Christus prakties te demonstreer teenoor alle mense nie. Juis deur Christus is vergewing en bevryding van sondes, ook seksuele sondes, moontlik. Elke gelowige het die plig om seker te maak dat hy/sy só optree dat God se genade nie verduister word nie, maar juis helder skyn. Daar moet dus simpatie en bewoëndheid wees, maar hierdie simpatie en bewoënheid maak nie dat 'n mens duidelike Skriftuurlike norme verander om aan te pas by die behoeftes en voorkeure van bepaalde individue nie. Soos wat 'n alkoholis géén alkohol mag gebruik nie, so sal die homoseksueel enige intieme kontak met persone van dieselfde geslag moet vermy. Dit mag selfs nodig wees om te besluit om géén seksuele verhouding te hê nie.

Die Skrifverklaarder en uiteindelik die prediker en pastor moet die homoseksueel tot die besef bring dat indien hy/sy met 'n homoseksuele verhouding volhard, dit op hartseer en selfvernietiging afstuur. Die homoseksueel moet egter hoor en ervaar dat daar in Christus genade is en dat daar vergewing by God is. Hy/sy moet besef:

27 Naas homoseksuele verhoudings word in Romeine 1:26-32 ook nog ander sondes genoem, soos kwaadpratery (1:29), skinder (1:30) en liefdelose hardvogtigheid (1:31). Baie gelowiges is deur God se genade dalk nie homoseksueel nie, maar hoe maklik word hulle nie self slagoffer van hulle natuurlike sondige geaardheid deur hulle skuldig te maak aan een van die ander sondes nie! Daarom die opdrag in Galasiërs 6:1-2 om sulke mense "in 'n gees van sagmoedigheid" te benader. 
Christus het ook vir hierdie sondige geneigdheid van my aan die kruis betaal! Dit is nou my opdrag om - al is dit in my geval dalk 'n lewenslange stryd - te stry téén dié sondige geneigdheid.

\section{Gevolgtrekking}

Snyman (2006:739) se standpunt dat geslagtelikheid nie bloot iets is "wat essensieël tot 'n mens se identiteit behoort nie, maar iets wat voortdurend gekonstrueer word op grond van sekere norme in die samelewing" en dat 'n man of 'n vrou nie 'n man of 'n vrou is "op grond van hulle anatomie nie, maar omdat die gemeenskap aan hulle sekere rolle toedig", veroorsaak dat hy die Skrifuitsprake oor homoseksualiteit relativeer tot tydgebonde uitsprake.

Daar is egter ook 'n verdere rede vir hierdie relativering: hy gaan uit van 'n subjektivistiese (relatiewe) waarheidsbeskouing. Die waarheid is vir hom iets wat gevorm word in die interaksie tussen leser en teks (vgl. Snyman, 2006:739), en dit lê nie (as geopenbaarde waarheid van God) in die teks self nie. Die waarheid is dus relatief en is 'n produk van die leser se "denkraamwerk". Daarom sy sterk fokus op heroorweging van die aard van seksualiteit in die lig van interseksualiteit, en sy oortuiging dat hierdie heroorweging Bybellees en -verstaan ingrypend moet beïnvloed.

Ek deel nie die spanning wat Snyman (2006:740) ervaar tussen Gereformeerdwees en tegelykertyd "as goeie landsburger die grondwet as hermeneutiese raamwerk" te aanvaar nie. Hy oordeel soos volg oor die uitwerking wat die grondwet as hermeneutiese raamwerk het: "Dié raamwerk lê daardie tekste wat homoseksualiteit afwys se onderliggende regverdiging van manlike oorheersing bloot. Gevolglik word die tekste se verwysing na seksuele omgang tussen lede van dieselfde geslag binne 'n bepaalde ideologiese raamwerk gegiet, wat in 'n ideologie van gelykberegtiging problematies geword het" (Snyman, 2006:740). Die probleem hiermee lê op drie vlakke:

- Die grondwet spreek hom nie uit oor die onderliggende ideologie van diskriminasie nie, maar oor die feit daarvan. Snyman se gevolgtrekking is dus 'n onhoudbare sprong. Die grondwet is wel die produk van sy eie ideologiese wortels (gelykberegtiging), maar dit kan nie goedskiks net so op die Skrif toegepas word nie.

- Snyman se konstruksie dat die Bybelse afwysing van homoseksualiteit eintlik 'n regverdiging van manlike oorheersing is, oortuig nie. Alhoewel die Bybel onmiskenbaar in 'n patriargale 
samelewing ontstaan het en die werklikhede daarvan verreken, stel dit ook in baie opsigte 'n korrektief op hierdie sosiale konteks. ${ }^{28}$

- Snyman se konstruksie dat die Grondwet se Handves van Regte nie die handhawing van die Bybelse verbod op homoseksuele verhoudings tussen Christene moontlik maak nie, is ongeldig.

Dit val op dat Snyman (2006:728) praat van "gesag wat aan die tekste toegeskryf word", gesag wat selektief aan tekste "toegedig" word (Snyman, 2006:728), tekste wat hulle oorredende gesag "verloor" (Snyman, 2006:730), tekste wat nie meer dieselfde "trefkrag" het nie (Snyman, 2006:733), en die Bybel wat nie meer sê "wat dit in die verlede gesê het nie" (Snyman, 2006:740) - alles aanduidings dat hy uitgaan van 'n subjektiwistiese waarheidsbeskouing wat nie die (objektiewe) waarheid van die geopenbaarde Bybelteks self erken nie.

Ek bly dus by my standpunt dat dit in die kern-Skrifuitsprake oor homoseksualiteit nie handel oor kultuur- of tydgebonde uitsprake nie, maar tydgerigte Skrifuitsprake is wat homoseksuele verhoudings verbied, en wat bevestig dat seksualiteit deur die Skrif beperk word tot die huwelik as 'n permanente vertrouensverhouding tussen twee persone, en dat die huwelik beperk word tot persone van teenoorgestelde geslagte. In die bostaande het ek aangetoon dat hierdie keuse teen die tydgebondenheid van die Skrifuitsprake en vir die tydgerigtheid daarvan, nie gedoen is op grond van onuitgesproke "duidelike ideologiese voorkeure" - soos Snyman (2006:718) beweer die geval is nie, maar op grond van eksplisiete Gereformeerde Skrifbeskoulike en hermeneutiese vertrekpunte.

Ek deel Snyman (2006:718) se versugting dat daar "'n etiek van Bybellees gekweek word waar Bybellesers nie bloot net die morele visie van die teks volg omdat dit in die Bybel staan nie". Wanneer Snyman (2006:718) egter as ideaal stel dat die Bybelleser moet "kan onderskei tussen dít wat kultureel bepaal en omlyn is en dít wat as geldende beginsels vir die huidige leser gestel kan word," roep dit vraagtekens op. Die hermeneutiese onderskeid tussen dít wat kultu-

28 Neem byvoorbeeld Hooglied met sy uitsig op 'n (seksuele) verhouding tussen twee persone van teenoorgestelde geslagte, waarin albei partye as gelyke vennote optree. ' $n$ Verdere argument is ook: alhoewel die Bybel onderdanigheid van die getroude vrou aan haar eie man leer, is die algemeen bekende patriargale gedagte dat alle vroue aan alle mans onderdanig is en minderwaardig is, nie 'n Bybelse leerstelling nie. 
reel bepaal en omlyn is en dít wat as ewige geldende beginsel vir die huidige leser gestel kan word, moet duideliker genuanseer word. In 'n sekere sin kan 'n mens sê dat alles wat in die Bybel staan kultureel bepaal en omlyn is, én dat alles wat in die Bybel staan, geldige beginsels vir die huidige leser behels. Die vraag moet dus nie wees of ' $n$ bepaalde uitspraak steeds geldig is nie, maar eerder hoe die uitspraak ook vandag geldig is. Hieroor is verdere navorsing nodig.

My uiteindelike oordeel is dus dat Snyman se artikel, ten spyte van goeie grepe, ons nie regtig nader aan die verwerkliking van die ideaal van onderskeidende Bybellees bring as wat reeds binne die paradigma van die huidige Gereformeerde Skrifbeskoulike en hermeneutiese vertrekpunte gebeur nie.

\section{Geraadpleegde bronne}

BERKHOF, L. 1971. Principles of Biblical interpretation. Grand Rapids: Baker Book House.

BOTHA, P.H. 2005a. Die sinode en homoseks: 'n kritiese evaluering van die homoseksulteitdebat in die NG Kerk in Suid Afrika. Kranskop: Khanya.

BOTHA, P.H. 2005b. The Bible and homosex: sexual truths for a modern society. Kranskop: Khanya.

BOTHA, P.H. \& VAN RENSBURG FIKA J. 2004. Homosexuality as against nature: an interpretation of Romans 1:26-27. Acta Patristica et Byzantinum, 15:38-56.

COETZEE, J.C. 1988. Gedagtestruktuurontleding en die eksgese van die Heilige Skrifte (In Coetzee, J.C., red. Koninkryk, Gees en Woord. Pretoria: NG Kerkboekhandel. p.19-37.)

COETZEE, J.C. 1995. Hermeneutics and exegesis of the New Testament. Part 1: Hermeneutical rules. Potchefstroom: Mini Publishers.

ELLIOTT, John H. 1981. A home for the homeless: a sociological exegesis of 1 Peter, its situation and strategy. Philadelphia: Fortress.

GREIJDANUS, S. 1946. Schriftbeginselen ter Schriftverklaring en historisch oversicht over theorieën en wijzen van Schriftuitleggen. Kampen: Kok.

GROSHEIDE, F.W. 1929. Hermeneutiek ten dienste van die bestudering van het Nieuwe Testament. Amsterdam: Van Bottenburg.

NEDERLANDSE GELOOFSBELYDENIS. 2003. (In Die berymde en omgedigde Psalms en ander Skrifberymings in gebruik by die Gereformeerde Kerke in Suid-Afrika. Wellington: NG Kerk Uitgewers. p. 5-32.)

NGB

kyk NEDERLANDSE GELOOFSBELYDENIS

POTGIETER, J. 2005. 'n Nuwe-Testamentiese studie in hermeneutiek: die homoseksualiteitsdebat in die Nederduitse Gereformeerde Kerk (19862004). Pretoria: Universiteit van Pretoria. (Ph.D.-proefskrif: ongepubliseerd.)

SNYMAN, Gerrie. 2006. Homoseksualiteit en tydgerigtheid: 'n etiek van Bybellees? In die Skriflig, 40(4):715-744. 
VAN RENSBURG, FIKA J. 2005. Hoe gedink oor homoseksuele verhoudings? Die Kerkblad: 10-11, Jan.

Kernbegrippe:

eksegese

hermeneutiek

Skrifbeskouing

Skrifhantering

Key concepts:

Bible: application of

Bible: view of

exegesis

hermeneutics 
